\title{
Maj Bylocks Drakskeppstrilogi: analogi och kulturmöten
}

http://urn.kb.se/resolve?urn=urn:nbn:se:sbi-32

Citation: Nordic Journal of ChildLit Aesthetics, Vol. 2, 2011 DOI: 10.3402/

blft.v2i0.5835

Abstract: In my thesis "It could just as well have happened today": Maj Bylock's Drakskeppstrilogi and historical consciousness in ten- to twelveyear-olds, I provide a textual, thematic analysis of the three novels from 1997-1998. Further, in an empirical study I have documented the reading of Bylock's fictitious, historical trilogy about the Viking era as done by 11-year-old children, whose thematic work and development of a historical consciousness also have been part of the study. This article deals only with the textual analysis aspect, which purpose is to show what in the texts might produce a historical consciousness in children as well as how the characters are portrayed in order for children to identify with them. Two functions of the novels are studied: knowledge and analogy. The focus is on the main character Petite/Åsa and her development with a view to gender, ethnicity and class as seen from an intersectional perspective. I use postcolonial concepts such as diaspora and hybrid identity in order to describe cultural encounters brought on by migration. I portray female characters gaining a higher level of empowerment, a term used by Joanne Brown and Nancy St. Clair. Bylock claims that she is reflecting the present in her historical texts and that this is more straightforwardly achieved when the events are set several hundred years ago. As a result irrelevant details can be removed and the focus be placed on timeless, human phenomena, for instance cultural encounters. In the light of the above and ideas about how best to describe cultural encounters I analyse the cultural contexts in which the main character finds herself focusing on her transition from a girl into a woman and her quest for a multicultural identity. I elaborate on the concepts mentioned in the previous by describing two cultural encounters which provide an analogy with the present.

Key words: Maj Bylock, migration, the viking age, historical consciousness, the historical novel, analogy, the perspective of being the other, empowerment, to read and write then and now. 
Dom tänker väl inte likadant på pricken men det är mycket som man tänker som är lika fortfarande. Det är det. Så det är rätt nyttigt (Emma, EIn3).

Jagharienempiriskstudie dokumenterat10-åringars och11-åringars läsning av Maj Bylocks fiktiva historiska trilogi om vikingatiden. Emma resonerar i sin tredje intervju med mig om hur människor tänkte på vikingatiden efter att ha läst och diskuterat Maj Bylocks Drakskeppet (1997). Inom denna didaktiska del av min forskning behandlar jag skönlitteraturens användning inom skolans samhällsorienterande ämnen. Sofie, Simon och Emma är tre elever som ingick i den klass 4-5 i södra Sverige, vars sex veckor långa tematiska arbete om Vikingatiden ligger till grund för min avhandling. I centrum stod dessa tre elever och deras fortlöpande utveckling av sitt historiemedvetande. De delgav mig i intervjuer hur de upplevde sin läsning av Maj Bylocks Drakskeppet (1997) och dess fortsättningar Det gyllne suärdet (1998) och Borgen i fjärran (1998).

I Bylocks Drakskeppstrilogi skildras hur Petite, en fransk adelsflicka, rövas bort av vikingar. Läsaren får följa hennes väg in i ett nytt samhälle i Norden. Hon beskrivs först i sin hemmiljö, men rövas bort av vikingar och säljs som träl. Hon rymmer och blir upphittad i skogen av en barnlös kvinna. På grund av den ofrivilliga migrationen genomgår Petite en mängd kulturmöten, något som också kan beröra våra dagars barn. Analogin till vår tid är uppenbar. Analogi i historiska romaner har tidigare till exempel studerats i $D a ̊$ som nu: historiska romaner i översikt och analys (Granlid 1964, 18).

I min avhandling presenterar jag utöver empirin en textanalys av Bylocks trilogi, vilket sammantaget gör avhandlingen till en litteraturpedagogisk studie av läsning med barn i mellanåldrarna och deras utveckling av historiemedvetande. Syftet med textanalysen är att visa vad det är i texterna som skulle kunna aktivera barns eget historiemedvetande och hur karaktärerna är skildrade för att barnen ska kunna identifiera sig med dem. I den här artikeln vill jag visa på en i huvudsak tematisk läsning av romanerna med någon anknytning till empirin som ovan.

Begreppet historiemedvetande har aktualiserats i samband med ett ökat intresse för historia från skola och samhälle. Klas-Göran Karlsson påminner i en artikel i Historien är nu: en introduktion till historiedidaktiken (Karlsson, Zander 2009) att begreppet sedan 1990-talet har spelat en nyckelroll i skolans målformuleringar för historieämnet (Kursplaner och betygskriterier 2000, 78) men parallellt studerar historiedidaktiker även hur detta medvetande formas i historiekulturen 
totalt. Karlsson skriver: "Varje människa har ett historiemedvetande, det vill säga vänder sig till, reflekterar över och integrerar historien i den egna identitets-bildningen, det egna vetandet och de egna handlingarna." (Karlsson, Zander 2009, 48) Med historiemedvetande menar jag: Vetskapen om att alla människor existerar i tid och rum, det vill säga att de har en härkomst och en framtid samt vetskapen om att ingenting är oföränderligt. Historiemedvetande handlar om tolkning av det förflutna, förståelse av nutiden och tankar om framtiden.

Jag studerar romanerna utifrån de två funktionerna intryck av kunskap och analogi (Pettersson 2002, 179-181). Jag fokuserar i analogianalysen på huvudkaraktären Petites/Åsas utveckling i ett intersektionellt perspektiv med tanke på kön, etnicitet och klass. Jag använder post-koloniala begrepp såsom diaspora och hybrididentitet (McLeod 2000, 219-227) för att beskriva kulturella möten orsakade av migration. Vidare porträtterar jag kvinnlig karaktärsutveckling på väg mot en högre grad av "empowerment", ett för analysen viktigt begrepp och i min översättning självbemyndigande (Brown, St. Clair 2002, 26f).

Hädanefter förkortas Drakskeppet (DS), Det gyllne svärdet (GS) och Borgen i Fjärran (BF).

\section{Kulturmöten då och nu}

Utifrån resonemangen ovan och idéer om hur kulturella möten kan beskrivas, analyserar jag de kulturella kontexter i vilka huvudkaraktären Petite/Åsa befinner sig med utgångspunkt i den lilla flickans utveckling fram till vuxen ålder, en berättelse om att hitta en mångkulturell identitet. Jag kommer att redogöra för ovan nämnda begrepp i samband med att jag beskriver två kulturella möten som visar på analogi med nutiden.

\section{Att vara den andre}

Drakskeppstrilogin presenterar, ur ett mångkulturellt perspektiv, huvudpersonens liv från flicka till vuxen kvinna. Det finns en grundläggande rörelse i romanerna. Karaktären Petite/Åsa blir genom sina upplevelser vad man med ett engelskt uttryck kan beskriva som "empowered", (Brown, St.Clair 2002, 10, 26-27) det vill säga självbemyndigad och jagförstärkt. Hon utvecklas först genom ett stort antal betydelsefulla möten med människor i hemlandet Frankerriket. Stora förändringar i hennes liv och utveckling sker också under båtfärden till Norden och under vistelsen på trälgården, i hemmet $\mathrm{i}$ vikingabyn och $\mathrm{i}$ hennes slutgiltiga hem i vikingaborgen. 
Petite/Åsa genomför under sin uppväxt, ett antal för karaktären, utvecklande, meningsfulla handlingar som för henne till en allt högre grad av "empowerment". Hon upplever isolering, utsätts för stora prövningar och introduceras därefter på nytt in i ett samhälle sagans klassiska mönster (Bettelheim 1979, 100). Då som nu var det många människor som migrerade, vilket skapar en rörelse i tid och rum och vikingatiden kan beskrivas som en mångkulturell period.

Drakskeppstrilogin skrevs mot slutet av 1990-talet (1997-1998) i en tid då invandringen till Sverige hade ökat. Ett stort antal barn från andra länder skulle under den här tiden anpassa sig till nya kulturmönster när de mottogs i det nya landet. De skulle också fungera i ett nytt skolväsende med andra levnadssätt än de var vana vid från hemlandet. Språket utgör vid all migration en stötesten, men om två språk kan utvecklas finns en möjlighet till ännu större utveckling både på kulturmötesnivå och på en allmänmänsklig nivå. Jag menar att allt detta liknar i stort den situation som huvudpersonen i Drakskeppstrilogin är placerad i.

Sverige är idag ett mångkulturellt land. Invandrade barns och ungdomars religion, deras erfarenhet av samhälle, familjeliv och skolgång skiljer sig från det de är vana vid från sina hemländer. Inger Nordheden menar emellertid i en artikel i Pedagogiska magasinet (Nordheden 2008) att Sverige alltid har varit mångkulturellt:

Men vad är egentligen svenskt? Och vad är turkiskt, kurdiskt
eller syrianskt? Egentligen är det en ointressant fråga. Hur
kan man behålla sin kulturella identitet och särart i ett nytt
land och hur kan vi etniska svenskar behålla vår? Vi omfor-
mas väl i alla möten? Vi påverkas väl i alla krockar. [...] Då
måste begreppet "Den Andre" problematiseras och lyftas
fram bland barn och ungdomar. Sverige är inte och har aldrig
varit ett monokulturellt samhälle. Det vet varje same, skåning
eller gotlänning. Med ökad invandring verkar det finnas ten-
denser att tro att det finns en värdegrund som är gemensam
för alla svenskar, vilket självklart inte är fallet. [...] I själva mö-
tet sker något nytt som genererar en ny identitet. Den nya identite-
ten är inte två identiteter, två kulturer som läggs till varandra, utan
en ny som inte tidigare fanns." (Nordheden 2008, 92, min kurs.)

Det finns anledning att ta Nordhedens synpunkter i beaktande. Hon trycker på de kulturella möten som sker hela tiden och att en ny identitet hos våra invandrare kan genereras genom dessa. Ett liknande skeende kan följas i Drakskeppstrilogin, där flera huvudkaraktärer omformas och huvudkaraktären uppträder som "den andre". 
Den andre är ett centralt begrepp inom sociologi och psykologi, där begreppet står för att vi behöver andra att jämföra oss med för att definiera oss själva. I den mänskliga naturen verkar finnas en benägenhet att idealisera sig själv och sin egen kultur. I Multikultiungdom: kön, etnicitet, identitet (Ålund 1997) beskrivs att våra dagars invandrare "blir definierade som 'främmande', som 'de Andra'"'(Ålund 1997, 10). Följden blir att fokusering på olikheter verkar för att förhindra att De blir likvärdiga med Oss.

Exempel på främmandeperspektivet i Drakskeppet är första gången när Petite tänker på vikingarna ur "den andre" - perspektivet. Bylock markerar tidigt i romanerna genom att Petite är den som får fokalisera vikingarnas utseende: "Alla de människor hon dittills hade sett hade haft svart eller mörkbrunt hår och brunsvarta ögon. Precis som hon själv. Hon rös och undrade om vikingarna verkligen var människor" (DS, 35). Petite distanserar sig mot bakgrund av sin erfarenhet. Hon som senare blir betraktad som den mörka och främmande, en karaktär från en främmande kultur, betraktar nu de ljusa vikingarna som avvikande. Kan man lära sig att se det egna med främmande ögon? Petite/Åsa reflekterar och synliggör för sig själv och för läsaren den etiska frågan när hon träffar nya människor.

När trältiden har bleknat, försöker Åsa ta sig ut i samhället. Då återstår en stor prövning: att vara den som är annorlunda och lära sig att hantera främlingsskapet. Nu är det omvänt; Åsa blir sedd som hon själv såg på vikingarna. Det centrala kapitlet har titeln "Vem vet varifrån vinterns vindar viner?"(DS, 102) När Åsa går ut i byn blir hon genast "den främmande". Boel och Stein har tagit emot flickan med få tvivel till skillnad från människorna i byn. För att slippa frågor har Boel berättat för byborna hur hon har hittat flickan och de kallar henne därför "Åsa hittebarn" (DS, 88). I smyg säger de: " - Ett barn som ser ut så där kan inte komma från gudarna. Det kommer säkert från trollen" (DS, 88). Detta uttalande påminner om Petites eget när hon såg vikingarna för första gången (DS, 35).

Åsa är alltså ännu inte accepterad. Vid midvinterfesten drar en av de vuxna byborna under rusets påverkan fram Åsa till elden. Han artikulerar det som flera av de vuxna har tänkt tidigare. "Vi tänker inte tåla att en trollunge växer upp bland våra barn"(DS, 104). Stein läser då en dikt som byborna får fundera på.

\footnotetext{
- Vem vet

varifrån vinterns vindar viner? $[\ldots]$
} 
Vem vet

varifrån vänner kommer?

Välkommen är hon

vilka vägar

hon än har vandrat (DS, 104).

"Trollungen" är "den andre" för byns befolkning. Dikten är didaktiskt uppfodrande och uppmanar läsaren till att välkomna människor med ett annat ursprung med ett öppet sinnelag. Inom sagovärden finns flera paralleller från folksagorna till "Bortbytingen" i Troll och människor (Lagerlöf 1915-1921).

Hon blir slutligen upptagen i byns gemenskap av den äldste $i$ byn."Han pekade på Åsa: - Ingen vet varifrån flickebarnet kommer. Men från och med nu är hon en av oss. Byborna mumlade: - Ja, från och med nu är hon en av oss" (DS, 106). Den inskrivne läsaren kan se att förändring är möjlig. Åsa känner sig nu tryggare men hon behåller hemligheten om sitt ursprung och tvekar att leka med de andra barnen. Några av dem har retat henne och förföljt henne för hennes mörka hår och annorlunda utseende. Åsa vet inget om vinter eller snö och får uppleva en ny prövning. "Det var som om någon hade skakat en jättestor säck med fågeldun över byn" (DS, 107). Boel uppmanar henne att leka:

Spring bort till de andra barnen, sa hon och föste ut henne ur stugan. Åsa var rädd men sprang ändå.[...] När barnen fick se henne blev de först tysta. Men en av de största flickorna drog henne med sej ut på isen. Då kom de andra också och lärde Åsa hur hon skulle åka kana. Huiiii! Snart flög hon som en virvelvind.[...] Det var bra länge sedan hon hade haft så roligt (DS, 108-109).

Att vara den andre är en stor utmaning, då som nu. Att flytta från sitt eget hemland och ofrivilligt börja ett nytt liv är en ännu större utmaning.

\section{Identitet och empowerment}

Nedan följer mitt andra analogiexempel i anslutning till gestaltningen av Petites/Åsas fortsatta identitetsutveckling. Jag beskrev tidigare Petites/Åsas väg i termer av isolering, prövningar och inträde i ett nytt samhälle (jfr s. 113). Nedan följer först analysförutsättningar. 
Huvudpersonens identitetsutveckling i Drakskeppstrilogin drivs på av de kulturmöten som är till följd av migration. Att skilja på klass, kön och etnicitet vad gäller Petite/Åsa är dock omöjligt. Hon är ett barn från riddarklassen, dessutom flicka och hon har ett annat etniskt ursprung än vikingarna. Maktperspektivet och förändringen i rumsliga och historiska sammanhang är då också viktiga att beskriva. Maktanalyser kan inte var för sig reduceras till en fråga om antingen kön, klass eller ras (De los Reyes, Molina, Mulinari 2005, 14). I detta sammanhang aktualiseras begreppet intersektionalitet. Syftet med en intersektionell analys är att "problematisera och synliggöra hur relationer av över- och underordning artikuleras i skilda historiska och rumsliga sammanhang. Den simultana effekten av kön, klass och etniska /"ras"- strukturer är en central komponent i maktens konstituering."(De los Reyes, Molina, Mulinari 2005, 7, 14)

Centralt $i$ analysen är Petites situation med förflyttning som ung marginaliserad flicka och med främmande ursprung. Analogin med nuet kan beskrivas på olika sätt. Identitet är starkt relaterat till etnicitet, vars betydelse verkar vara vidare än ras och inkludera sociala praktiker, ritualer och traditioner i syfte att identifiera olika kollektiva grupper (McLeod 2000, 111).

Vilka aspekter av diaspora, i betydelsen förskingring, kan vara användbara vid denna litteraturanalys, som ska beskriva Petites speciella situation? Robin Cohen skriver i Global diasporas: an introduction (2008) om nio olika särdrag som diasporan kan uppvisa, bland andra: förskingring från hemlandet, idealisering av det förmodade gamla hemmet, ett besvärligt förhållande till värdsamhällen och möjligheten till ett berikande liv i toleranta värdländer (Cohen 2008, 161-162).

I alla kulturmöten utvecklas människor och identitet förändras. McLeod uttrycker hur individens identitet kan växa fram "from the process of hybridisation". Med begreppet hybrididentitet betonar McLeod den rörlighet som finns i individens utveckling. McLeod skriver även om skönlitteratur som gestaltar" hybrid identities at the 'in - between"' och "living 'in between' - from roots to routes". Att leva "in - between" innebär att man har svårt att känna sig hemma i någon av kulturerna, både den nya och den gamla, och det kan också vara smärtsamt och marginaliserande. Samtidigt möjliggör dessa förhållanden en utveckling av den egna identiteten. Det sätt identiteten utvecklas på kan beskrivas som "roots to routes", det träffande uttrycket "rötter blir vägar"(McLeod 2000, 218-225).

Karaktären Petite gestaltar flera av de ovan beskrivna förhållandena. Brown och St.Clair menar att det mångkulturella samhället 
i USA har drivit fram en vilja att återigen söka de historiska perspektiven samt lyfta fram försummade sammanhang från förr och omvärderingar av det förgångna. Först nyligen har författare börjat ägna intresse åt flickors och kvinnors liv i det förflutna, en utveckling som de inte hade kunnat föreställa sig (Brown, St.Clair 2002, 53). Nu har det emellertid blivit dags att beskriva de kvinnliga, självständiga hjältarna.

Utvecklingen Brown och St. Clair beskriver ter sig likadan i Sverige på 1990-talet: invandringen och de kulturella mötena behöver belysning i fiktionen och ofta förläggs då handlingen till historisk tid och med flickor som hjältar. Den redan nämnda termen "empowerment" använder Brown och St.Clair för att beskriva utvecklingen för flickkaraktärerna: "empowerment as a nourishing belief in capacity and competence." (Brown, St.Clair 2002, 27) Genusperspektivet är också starkt kopplat till identitetsutvecklingen hos det växande jaget.

Under andra halvan av 1900-talet publicerades historiska romaner i USA med skildringar av "empowered girls", självbemyndigade flickor som utvecklades under sin uppväxttid (Brown, St.Clair 2002, 26).

Redan på 1980-talet fanns i Sverige historiska romaner en koppling mellan genus och klass. Minnet av det förflutna: motiv $i$ den moderna historiska ungdomsromanen (Toijer-Nilsson 1987) innehåller beskrivning och analys av ett stort antal barn- och ungdomsromaner med historiskt innehåll, varav flera handlar om migration. Toijer-Nilsson inleder med att "historiens kraftkvinnor, som brutit sig loss ur konventionerna, har någon gång blivit skildrade i ungdomsböckerna [...]." (Toijer-Nilsson 1987, 124) Hon konstaterar att om läsaren vill hitta litteratur om flickor med ett spännande liv inom genren historiska romaner får man i första hand gå till emigrantlitteraturen, eftersom pojkkaraktärer i övrigt är överrepresenterade som huvudpersoner (Toijer-Nilsson 1987, 114). Utveckling av flickkaraktärer i emigrantlitteraturen har kraftigt förstärkts under 1990-talet.

Det är också rimligt att tro att de författare som nu skriver historiska romaner har påverkats av den debatt som finns idag om kvinnors villkor och därmed lägger in nutida värderingar i romanerna.

Det finns således ett starkt samband mellan migration och klass och genus i historiska romaner med flickkaraktärer i huvudrollen. I nyare historiska romaner finns också ett starkare fokus på etnicitet, en aspekt av dessa flickors liv. En motsvarighet till Browns och 
St.Clairs översikt och analys av nyare historiska romaner saknas ännu i Sverige.

En grundläggande fråga är hur Petite/Åsa med sitt utgångsläge kan skaffa sig "empowerment", självbemyndigande (jfr s. 112). Utgångspunkten för resonemanget är att visa Petites start och väg ut i livet. Att ge sig ut i världen och utsättas för prövningar är självbemyndigande och tillhör också den klassiska sagans ingredienser; tidigare ofta förbehållet män.

Brown och St. Clair noterar att skönlitteratur riktad till unga läsare med pojkar och unga män i huvudrollen, nästan alltid följer ett rituellt mönster som för huvudpersonen från oskuldsfullhet till erfarenhet. Skildringen av självbemyndigade flickor följer ofta ett initiatoriskt mönster i tre steg/stadier med rötter i primitiva samhällen (Brown, St.Clair 2002, 27).

Definitionen av "empowered girls" måste därför inkludera att "empowerment" har mer att göra med att flickorna skaffar sig tillit till sina egna resurser än att få makt över andra. Egenskapen kan beskrivas som social kompetens med balans mellan omsorg om andra och självbemyndigande, en balans mellan lojalitet och frihet. Jag betraktar självbemyndigande i en kvinnlig utvecklingsroman som en slags positiv utvecklingsbar egenskap, en kraft som dessa flickor och kvinnor utvecklar. När kvinnorna väl har erhållit denna kraft, som också kan beskrivas som makt, delar de den och använder sin auktoritet till att ge andra makt. Brown och St.Clair uttrycker det så här: "Meaningful empowerment should result from purposeful action rather than from innate talent or coincidental circumstances."(Brown, St.Clair 2002, 27, min kurs)

\section{Att kunna läsa och skriva}

Nedan fortsätter gestaltningen av Petites/Åsas fortsatta utveckling genom möten, ett annat sorts kulturmöte. Läsning och skrivande är en väg till självbemyndigande och tematiseras genom alla tre romanerna. Under anpassningen till Boels och Steins liv går Åsas liv utvecklingsmässigt in i en ny fas. Hemligheten med att hon kan läsa på franska röjer emellertid inte Åsa på många år, inte förrän hon inser att hon kan hjälpa Stein med det gyllne svärdets hemlighet. Då är hon nästan vuxen och hennes kunskap blir avgörande för fosterfadern Steins räddning (DS, 86).

Att kunna läsa hade olika betydelse i Frankerriket och hos vikingarna i Norden och lyfts fram redan från början i Drakskeppet, Men det är inte flickan Petite som får tillgång till skriften i hemmet. 
Över de bruna sidorna trängdes svarta tecken på papper. Läraren pustade och torkade svetten ur panna. Riddarens söner var tröglärda. Det var ett tungt arbete att lära dem läsa. Petite hade istället lätt för att lära. För henne var alltihop spännande som en lek [...]. Men att hon kunde läsa vågade hon inte andas om, så det blev hennes hemlighet (DS, 13-14, min kurs.)

Berättaren visar för den unge läsaren med uttrycket "svarta tecken på papper" att i Frankerriket finns det redan en skrivkultur när det var vikingatid i Norden. Skrivmöjligheterna var annorlunda i Norden. För Petite är läsningen "spännande som en lek".

Vår tids barn kan känna igen sig både i Petites glädje att lära sig läsa och i brödernas önskan att hellre vilja leka ute. Läsning är en viktig kunskap för den samhällsklass familjen tillhör. Petites synpunkter på denna könsskillnad får läsaren reda genom berättaren, som tydliggör kontraster i genushänseende. Berättarens röst anger vad pojkarna helst vill göra. "Pojkarna slapp sitta stilla inne i borgen och läsa i den tråkiga boken" (DS, 21). För Petite är läsning däremot en utmaning. Bylocks didaktiska ambitioner röjs och analogin till nutiden är klar. Budskapet genom romanerna till läsaren blir att den som kan läsa har fördelar och kan hävda sig bättre i framtiden.

Åsa hittar själv metoder och skapar kunskap när hon lär sig läsa på det nya språket: "Åsa tog upp en stenflisa och ritade en runa i jorden på golvet. Bredvid den skrev hon vad tecknet hette på hennes eget språk. Dagarna gick och Åsa lärde sig alltmer. När vintern kom förstod hon nästan allt Boel och Stein sa" (DS, 91).

När hon känner sig trygg med Stein, börjar hon följa hans arbete med runstenar. Avsnittet som handlar om texten på runstenarna heter "De mystiska tecknen" att jämföra med svarta tecken på papper i Frankerrikets handskrivna dokument.

Tecken som Stein ristade kallades runor, och runorna hörde ihop med trolldom. Eftersom Stein kunde rista runor var byborna säkra på att han också kunde trolla. [...] Andra bad honom rista en trollramsa på en träbit eller en sten som de kunde bära med sej. De hoppades att runorna skulle skydda dem mot sådant som var farligt. Byborna vågade inte bli ovänner med Stein (DS, 88-90).

Läsaren, men inte Stein, vet att Åsa kan läsa på franska vilket ökar spänningen för läsaren och möjliggör förståelsen av berättelsen. Bylock använder olika fokalisatorer. Det gyllne svärdet har en för 
vikingarna oläslig inskription. Läsaren börjar ana vad texten på det gyllne svärdet kommer att kunna berätta och kan också förstå vilken inverkan runstenarnas text får på Åsa, vars intresse för deras budskap är logiskt. Runstenarnas text kan ge ledtrådar till varför hon blev bortrövad och kan dessutom ge Àsa förutsättningar att kunna återvända till hemmet. Så väver Bylock ihop trådarna, som handlar om att erövra språket, förr som nu.

Helst satt hon och såg på när Stein ristade runor. Hon satt så nära att hon kunde se vartenda streck han ristade i stenen. Aaa, sa han och pekade på runorna. - Sss, fortsatte han och pekade på nästa. Tttt... Plötsligt skrattade Åsa till. Nu förstod hon. Steins a såg inte ut som hennes, men det var ändå ett a. Man kunde skriva a på olika sätt. Läste man Åsas bokstäver tillsammans blev det ord. Kanske blev det ord också av runorna? Orden i boken hemma hade något att berätta. Det kanske runor också hade? $\mathrm{Nu}$ blev de långa ringlande raderna av runor spännande. [...] Åsa tog upp en stenflisa och ritade en runa i jorden på golvet. Bredvid den skrev hon sedan vad tecknet hette på hennes eget språk (DS, 91, min kurs).

Åsa är en läraktig motiverad elev till Stein och han är en tålmodig lärare. Åsa kopplar runorna till "orden i boken hemma". Ordet bok förekommer för första gången. Texten blir en lektion i läsning med ljudningsmetoden. Motivationen att lära sig skriva höjs när hon identifierar de ord och bokstäver hon kan på det främmande språket. Hon har "knäckt läskoden", i det här fallet runkoden. Då kan hon också förstå meddelandena på runstenarna, som både innehåller berättelser om resor och är dödsrunor. Hon kunde också läsa vad som stod på stenen. Där stod:

\author{
Starke reste stenen \\ efter sin son Vidar Viking. \\ Vidar for med sitt skepp \\ till Frankerriket för att finna guld (DS, 91-100).
}

Åsa får fördjupade kunskaper om språket i Norden och även kunskap om vikingafärder. Kunskaper i det egna modersmålet hjälper henne att lära sig det nya språket och hon bekräftar sin läsförmåga. Åsa blir tvåspråkig. Läsning blir också en väg in i vikingasamhället liksom för nutida barn in i vårt samhälle. Sensmoralen är uppenbar: lär dig läsa så att du kan hävda dig i samhället och hantera svåra situationer och kanske också få makt som Stein. Då som nu är kunskap och läs- och skrivförmåga makt. Läsningen för Åsa vidare i hennes utveckling. 


\section{Avslutande reflektioner}

Vikingatiden var en tid av migration och analogin till vår tid är som visats omfattande. Barn och ungdomar som har flyttat till vårt land kan identifiera sig i utanförskapet och i språkfrågan.

När dagens barn och ungdomar från andra länder möter kulturyttringar idag i Sverige, blir det ofrånkomligt möten på olika villkor. Vid en jämförelse med Petites/Åsa och kunskapsfärd in i det nya samhället och dagens migranter finns paralleller. Att människor lever med hybrididentitet är lika aktuellt då som nu. Integrering av "den andre" kan vara lika svårt. Maj Bylock, som skrivit många historiska romaner för unga läsare är tydlig när det gäller paralleller till barns liv idag:

Jag tycker att det är fascinerande med historia. Det är viktigt för barn att få veta hur det var förr för att få referensramar till sina egna liv. Det finns också mycket i gammal tid som hjälper mig att berätta om det som händer i nutiden. Jag speglar nutiden både fakta- och idémässigt i de historiska skildringarna. Det är lättare att renodla när man förlägger handlingen några hundra år tillbaka i tiden. Man kan skala bort oväsentligheter för att ta fram mänskliga problem som är tidlösa och allmängiltiga ("Varför skriver du historiska böcker?: Opsis ställde frågan till några aktuella författare" Opsis Kalopsis, 1993:1, 20).

Biografisk information: Mary Ingemansson, lektor i svenska, inriktning litteraturvetenskap vid Högskolan i Kristianstad. Disputerade 2010 vid Lunds universitet med avhandlingen "Det kunde lika gärna ha hänt idag". Maj Bylocks Drakskeppstrilogi och historiemedvetande hos barn i mellanåldrarna. Kontakt: mary.ingemansson@hkr.se

\section{Bibliografi}

Bettelheim, Bruno. Sagans förtrollade värld: folksagornas innebörd och betydelse. Stockholm: Awe/Geber, 1979.

Brown, Joanne, Nancy St.Clair. Declarations of independence: empowered girls in young adult fiction. Lanham, Maryland: Scarecrow press Inc., 2002.

Bylock, Maj. Borgen i fjärran. Stockholm: Rabén \& Sjögren,1998.

Bylock, Maj. Det gyllne svärdet. Stockholm: Rabén \& Sjögren,1998.

Bylock, Maj. Drakskeppet. Stockholm: Rabén \& Sjögren,1997. 
Cohen, Robin. Global diasporas: an introduction. London: Routledge, 2008.

De los Reyes, Paulina, Mulinari, Diana. Intersektionalitet: kritiska reflektioner över (o)jämlikhetens landskap. Malmö: Liber, 2005.

Granlid, Hans. Då och nu: historiska romaner i översikt och analys. Stockholm: Natur och kultur, 1964.

Karlsson, Klas-Göran. "Historiedidaktik: begrepp, teori och analys". I Historien är nu: en introduktion till historiedidaktiken. Klas-Göran Karlsson \& Ulf Zander, Lund: Studentlitteratur, 2009.

Kursplaner och betygskriterier 2000. Grundskolan, reviderad version 208. Kursplan för historia. Skolverket: Stockholm, 2000.

Lagerlöf, Selma. "Bortbytingen". I Troll och människor. Stockholm: Bonniers, 1915-1921.

McLeod, John. Beginning postcolonialism. Manchester: Manchester UP, 2000.

Nordheden, Inger. "Ps. Krönika". Pedagogiska magasinet nr 3, Tema: Att leda lärande, september 2008.

Opsis Kalopsis. "Varför skriver du historiska böcker?: Opsis ställde frågan till några aktuella författare". Opsis Kalopsis. Red. Birgitta Fransson. Stockholm, (1993) 1.

Pettersson, Torsten. Dolda principer: kultur- och litteraturteoretiska studier. Lund: Bibliotekstjänst, 2002.

Toijer-Nilsson, Ying. Minnet av det förflutna: motiv i den moderna historiska ungdomsromanen. Stockholm: Rabén \& Sjögren, 1987.

Ålund, Aleksandra. Multikultiungdom: kön, etnicitet, identitet. Lund: Studentlitteratur, 1997.

Note: This article is being published simultaneously in Barnboken - tidskrift för barnlitteraturforskning/Journal of Children's Literature Research and Nordic ChildLit Aesthetics/Barnelitterært forskningstidsskrift 